\title{
Survey of potential insect vectors of Rice Yellow Mottle Virus in the Southern and Central rice basin of Benin
}

\author{
Augustin KOUDAMILOROํㅗ Abou TOGOLA², Angelo Cocou DJIHINTO33, Ouorou Kobi DOURO- \\ KPINDOU4, Martin AKOGBETO1 \\ 1 Département de Zoologie, FAST, BP 526 Cotonou, Université d'Abomey-Calavi, Abomey-Calavi, Benin, \\ 2International Institute of Tropical Agriculture, PMB 3112 Kano, Kano State, Nigeria, \\ 3Institut National des Recherches Agricoles du Bénin (INRAB), 01 BP 884 Cotonou, Benin \\ 4International Institute of Tropical Agriculture (IITA), 08 BP 0932, Cotonou, Benin \\ Corresponding Author: Augustin KOUDAMILORO, Address: BP 526 Cotonou (Bénin) \\ Tel: + 229978699 64; Email: koudaugus@yahoo.fr
}

Original submitted in on $3^{\text {rd }}$ October 2018. Published online at www.m.elewa.org on $31^{\text {st }}$ January 2019 https://dx.doi.org/10.4314/jab.v133i1.3

\begin{abstract}
Objectives: Insects are considered as the main vectors of Rice Yellow Mottle Virus (RYMV) in Africa. However, in Benin, little is known about the abundance and diversity of potential insect vectors of RYMV in rice fields to prevent and manage disease impact on rice production.

Methodology and Results: The inventory of the potential insect vectors of this disease was carried out in the rice basin of the Southern and Central of Benin where three sites namely AfricaRice station, Koussin and Ouedeme, were prospected. The sweep net technique, visual observation and yellow plates trap were used to conduct the surveys. Eighty insect species belonging to 28 families and 8 orders were recorded at rice tillering, booting, heading and maturation stages. Variation of insect diversity was low among the sites. The shorthorned grasshopper Oxya hyla (Serville), the ladybird beetle Chnootriba similis (Mulsant), the rice white leafhopper Cofana spectra (Distant) and the stalk-eyed fly Diopsis thoracica (Westwood) were the most important species considering their relative abundance $(10.62 \%, 5.19 \%, 7.99 \%$ and $7.01 \%$, respectively) and frequency of occurrence $(90 \%, 80 \%, 73.33 \%$ and $80 \%$, respectively). These insects were mostly present at tillering and booting stages.

Conclusion and application of results: Seventy-five $(75 \%)$ of the recorded species were not identified as RYMV vectors before. Special attention must be paid to the distribution and importance of these insects in the fields. Studies on their ability to transmit RYMV according ecological conditions should be done to know high-risk production areas and to prevent large epidemics of RYMV.

Keywords: Rice-feeding insects, West Africa, virus transmission, relative abundance, occurrence, rice ecology

\section{INTRODUCTION}

Rice is one of the most produced and consumed cereals in West Africa. Similarly, to all cereals, rice production is constrained by several diseases.

Several studies found that Rice Yellow Mottle Virus (RYMV) is one of the main constraints to rice production (Séré et al., 2008; Onwughalu et al.,
\end{abstract}


2010, 2011). Yield losses due to RYMV were estimated between 5-100\% (Banwo et al., 2004; Alegbejo et al., 2006). In Benin, this disease was identified for the first time in 1999 (Konaté et al., 2008). Its presence was confirmed later by the AfricaRice pathology unit (AfricaRice, 2008, unpublished data). It has been proven that insects are the main vectors of RYMV (Bakker, 1971; Nwilene et al., 2009). Rats, birds (Peters et al., 2012), domestic animals like cattle and donkeys (Sarra \& Peters, 2003), and manure (Calvert et al., 2003) are RYMV vectors. Rice plant is an ideal host for most insect species. All plant parts are fed by various insect species. In West Africa, some prospections carried out mainly in Côte d'Ivoire, Senegal, Nigeria, Guinea and Guinea-Bissau reported approximately 330 insect species in rice fields (Heinrichs \& Barrion, 2004). They are all considered as potential vectors of RYMV due to their presence in these fields (Nwilene, 1999). In Benin, Little research has been done on the diversity of insect pests in rice fields and are mainly related to stem borers (Togola et al., 2010; Togola et al., 2011), root termites (Togola et al., 2012) and storage insects (Togola et al., 2014). However, for a better understanding of the RYMV epidemiology and its distribution, the entomofauna of potential vectors should be known. The present study aims therefore at inventorying the insect pests, potential vectors of RYMV in Southern and Central basin of the rice production in Benin.

\section{MATERIALS AND METHODS}

Study region: Surveys were conducted from November 2009 to September 2010. Three sampling sites in the Southern and Central rice basin where RYMV isolates were identified (AfricaRice unpublished data, 2010). The sites were localized in Ouedeme ( $\mathrm{N} \mathrm{06} 6^{\circ} 42^{\prime} 57^{\prime \prime}, \mathrm{E}$ $\left.01^{\circ} 40^{\prime} 54^{\prime \prime}\right)$, Koussin (N 07 $14^{\prime} 34^{\prime \prime}$, E 02 $17^{\prime} 19^{\prime \prime}$ ) and AfricaRice-Cotonou station (N 6 25'10", E 2¹9'83") (Figure 1).

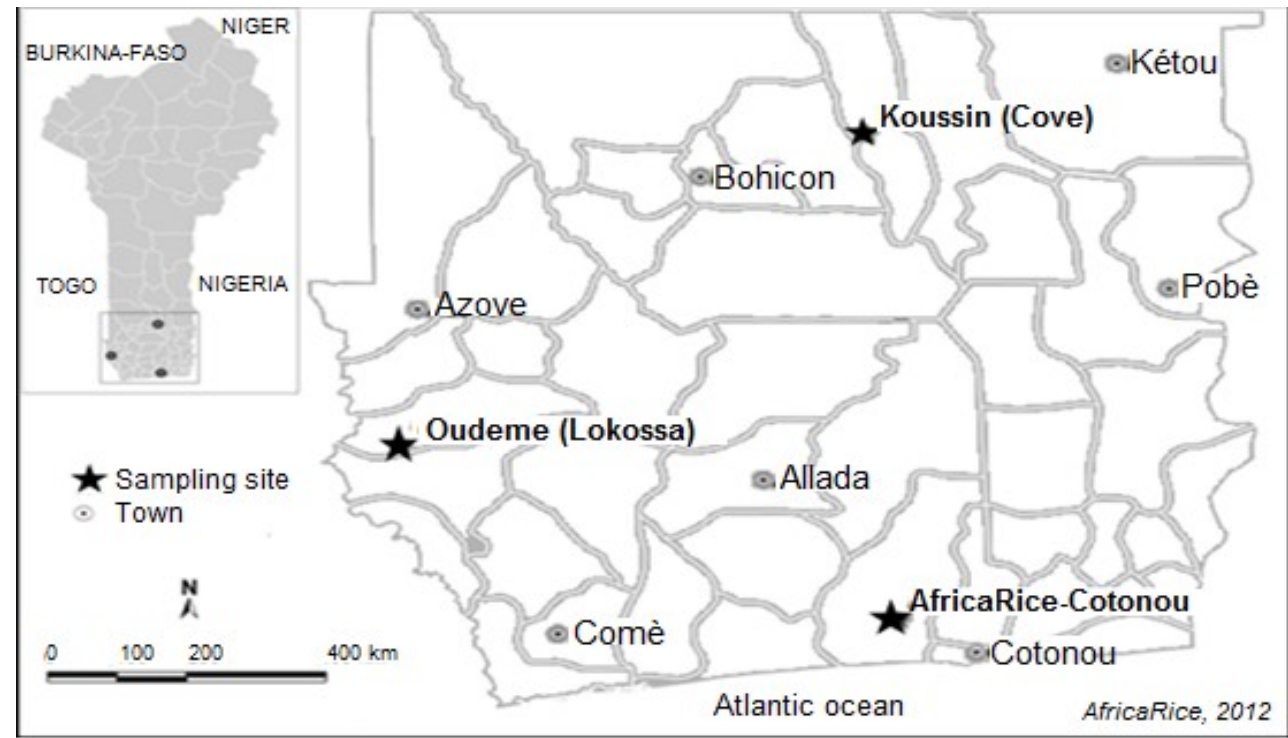

Figure 1. Rice basin in Southern and Central Benin.

Ouedeme and Koussin sites were irrigated lowland ecosystem where rice is essentially cultivated. AfricaRice site is research station with irrigated lowland and upland ecosystems of rice production. Maize, cowpea, cassava and market gardening were also grown besides rice fields in this station. For the three sites, rice is continuously growing throughout the year due to favorable climatic conditions.
Sampling Methods: For each site, surveys were carried out during tillering, booting, heading and maturation stages of rice development in lowland system. A plot of $3600 \mathrm{~m}^{2}$ was randomly selected for each stage. No insecticide was applied on such plots. Each developmental stage was sampled using the techniques of sweep net (Sadou et al., 2008), visual observation and yellow plates trap. For sweet net, 360 mowing were 
carried out for each developmental stage. Due to the high mobility of some insect species, visual observation was done. It entails counting all observed insects on one the diagonal of the field. These insects were reported and briefly described. The small and low mobile insects were collected using a small mouth aspirator. The last technique used, was catching the maximum number of insect species with yellow plates (Roth, 1963; Rolot, 2005). Yellow color is known to attract most flying insects (Dupriez et al., 2001). Nine plastic plates of $20 \mathrm{~cm}$ width each and $10 \mathrm{~cm}$ depth (Sylvie, 1995), were filled with soapy water and placed on tutors at each rice stage. To prevent the decomposition and discoloration of trapped insects, $10 \mathrm{~g}$ of table salt were added in the soapy water (Limoges, 2003). Each developmental stage was sampled once for each site.

Period and sequence of sampling: For each rice developmental stage, visual observation was firstly done. Thereafter, yellow plate traps were placed in the sampling area for two days before net sweeping was performed. The sweep net was used only during tillering and booting. Trapped insects with the plates were carefully recovered by water filtering through a fine mesh. Trapped insects with sweep net were conserved into fine mesh cages containing the rice plants and brought back to the laboratory where sorting was done to separate and rear insect larvae not yet identifiable. Trapped adult specimens were also preserved in $70 \%$ ethanol considering the site, development stages, technique and data of sampling before the identification.

Identification of insect specimens: Identification of insect specimens was done in the laboratory of entomology at AfricaRice-Benin using the identification key of insects (Heinrichs, 1983), the key of insect families (Delvare \& Aberleng, 1989) and the manual of the insect pests of rice and their natural enemies in West Africa (Heinrichs \& Barrion, 2004). In addition, the reference collections of the IITA-Benin insectarium were used for fine-tuning the identification. Insects were thereafter counted and classified by species.

Statistical analysis: To determine the relative proportion of species and orders of the identified insects, Chi-square

\section{RESULTS}

Variation of insect diversity in the rice basin: The values of related Evenness of Shannon (near 1) and Simpson (near 0) indices showed low variation on diversity of insect species based on rice developmental stages in (Table 1) and sites (Table 2). All these indices were similar in value and did not show a significant difference on pest richness. In total, 80 insect species test was performed. The relative abundance and frequency of occurrence of the insect species were calculated to assess the importance and distribution. The relative abundance $(A)$ of a species is the ratio of individuals of the species to the total number of specimens of all species. It is computed using the following formula:

$A=\frac{\mathrm{Na}}{\mathrm{Na}+\mathrm{Nb}+\mathrm{Nc}+\mathrm{N}_{\ldots}} * 100$ Where $A$ is the Relative abundance and $\mathrm{Na}, \mathrm{Nb}, \mathrm{Nc}$ are the number of specimens respectively for species $a, b$ and $c$.

The frequency of occurrence $(F)$ is the sample percentage in which a given species was present relative to the total of samples collected (Dajoz, 1985; Alhmedi et al., 2007). The formula used is as follow: $F=\frac{P a}{P} * 100$, where $F$ is the frequency of occurrence of each species, $P a$ is the number of samples containing the species and $P$ is the total number of samples collected. There are four (4) groups of frequency of occurrence (Dajoz, 1985): Group 1 (constant species with $50 \%$ or more of the total sample), Group 2 (accessory species that occur between $25-49 \%$ of the total sample), Group 3 (accidental species that occur in 10 to $24 \%$ of the total sample) and Group 4 (sporadic species which occur in less than $9 \%$ of the total sample). The diversity indices were determined for the rice growing stages and for each site. The Shannonwiener index (1) and its related Evenness Index (2), Simpson's index (3) and its related Evenness Index (4). The reciprocal form of Simpson index was used as indicated by Magurran (2004):

(1) $H^{\prime}=-\sum_{i=1}^{S} p_{i} \ln p_{i}$;

(2) $I^{\prime}=H^{\prime} / H_{\max }=H^{\prime} / \ln S$;

(3) $D=\sum_{i}^{S}\left(\frac{n_{i}\left(n_{i}-1\right)}{N(N-1)}\right)$; (4) $E_{1 / D}=\frac{(1 / D)}{S}$ where $p_{i}=$ $n_{i} / N ; n_{i}$ is the number of individuals in the ith species; $N=$ the total individuals in the sample and $S=$ the total number of species.

belonged to 8 orders, 28 families were found. A significant difference was observed between the different orders in the three sites $(P<0.0001)$. Generally, Homoptera, Orthoptera, Coleoptera and Diptera orders were the most predominant $(P<0.0001)$ (Figure 2). Thirty-nine insect species distributed into 20 families were reported in both sites. 
Table 1: Insect diversity Indices at different rice developmental stages

\begin{tabular}{l|c|c|c|c|c|c}
\hline Stage & Site & S & $\mathbf{H}^{\prime}$ & $\mathbf{J}^{\prime}$ & $\mathbf{1 / D}$ & $\mathbf{E}_{1 / \mathbf{D}}$ \\
\hline \multirow{3}{*}{ Tillering } & AfricaRice & 46 & 2.84 & 0.74 & 23.20 & 0.50 \\
& Koussin & 41 & 2.88 & 0.77 & 12.31 & 0.30 \\
& Ouedeme & 40 & 2.94 & 0.79 & 12.82 & 0.32 \\
Booting & AfricaRice & 54 & 3.42 & 0.86 & 23.52 & 0.43 \\
& Koussin & 45 & 2.80 & 0.74 & 10.50 & 0.23 \\
Heading & Ouedeme & 44 & 2.99 & 0.79 & 13.17 & 0.30 \\
& AfricaRice & 42 & 2.30 & 0.62 & 5.29 & 0.12 \\
& Koussin & 35 & 2.81 & 0.79 & 9.56 & 0.27 \\
Maturation & Ouedeme & 35 & 2.92 & 0.82 & 13.26 & 0.38 \\
& AfricaRice & 22 & 1.91 & 0.61 & 4.60 & 0.21 \\
& Koussin & 20 & 2.30 & 0.77 & 6.99 & 0.35 \\
& Ouedeme & 18 & 1.98 & 0.69 & 3.98 & 0.22 \\
\hline
\end{tabular}

S: Max diversity, H': Shannon-wiener index, J': related Evenness index of Shannon, 1/D: Simpson's index, $E_{1 / D}$ : related Evenness of Simpson

Table 2: Insect diversity Indices in the different prospection sites

\begin{tabular}{l|c|c|c|c|c}
\hline Site & S & H' $^{\prime}$ & $\mathbf{J}^{\prime}$ & 1/D & $\mathbf{E}_{1 / \mathrm{D}}$ \\
\hline AfricaRice & 68 & 3.43 & 0.81 & 17.33 & 0.25 \\
Koussin & 58 & 3.04 & 0.75 & 12.85 & 0.22 \\
Ouedeme & 53 & 3.21 & 0.81 & 16.34 & 0.31 \\
\hline
\end{tabular}

S: Max diversity, H': Shannon-wiener index, J': related Evenness index of Shannon, 1/D: Simpson's index, $E_{1 / D}$ : related Evenness of Simpson

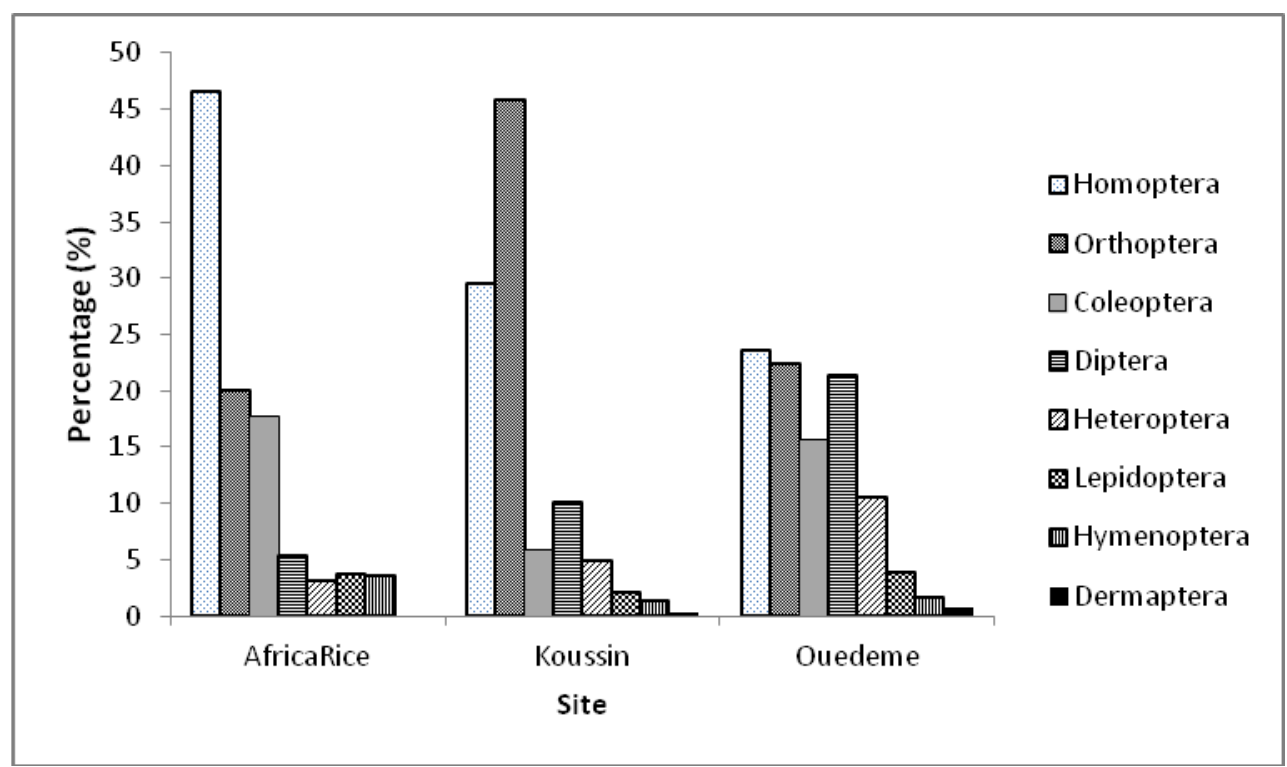

Figure 2. Insect orders distribution in the Southern and Central Benin rice basin.

Diversity and abundance of insect orders by rice growing stage at AfricaRice: At AfricaRice, 7 orders, 26 families and 68 species were identified. Despite the nonsignificant difference $(P=0.12)$ between them, Orthoptera (20.59\%), Coleoptera (20.59\%) and
Homoptera (17.65\%) were the most frequent considering insect species. Diptera $(4.41 \%)$ were less sampled. Homoptera order was dominant in all developmental stages (Figure 3). 


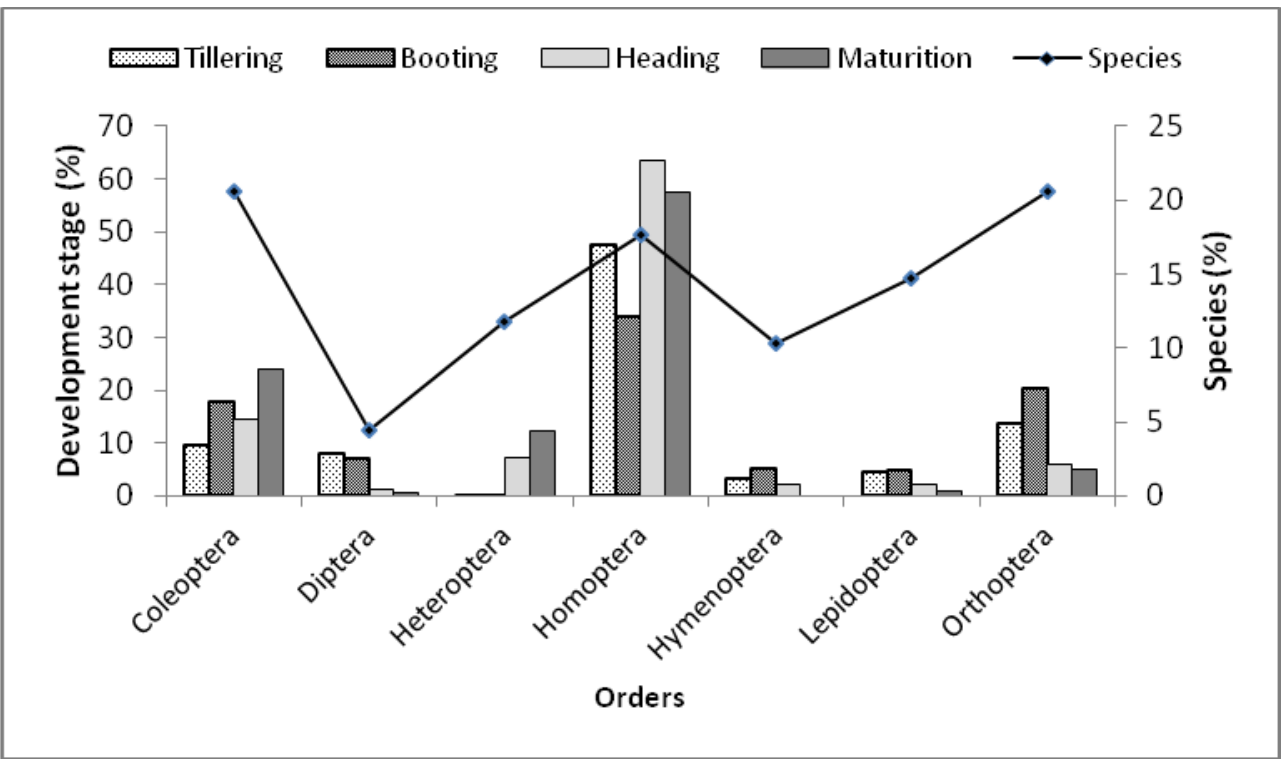

Figure 3: Diversity and abundance of insect orders according rice developmental stages in AfricaRice site.

Diversity and abundance of insect orders by rice growing stage at Koussin: Eight orders, 25 families and 58 species were reported at Koussin. Orthoptera were the most abundant order with $34.45 \%, 54.76 \%, 46.88 \%$ and $38.89 \%$ of species respectively at tillering, booting, heading and maturation. A significant difference $(P=$ 0.03 ) was observed between orders in terms of number of species with predominance of Homoptera $(22.41 \%)$, followed by Orthoptera (18.97\%), Coleoptera (15.52\%) and Lepidoptera (15.52\%) orders (Figure 4).

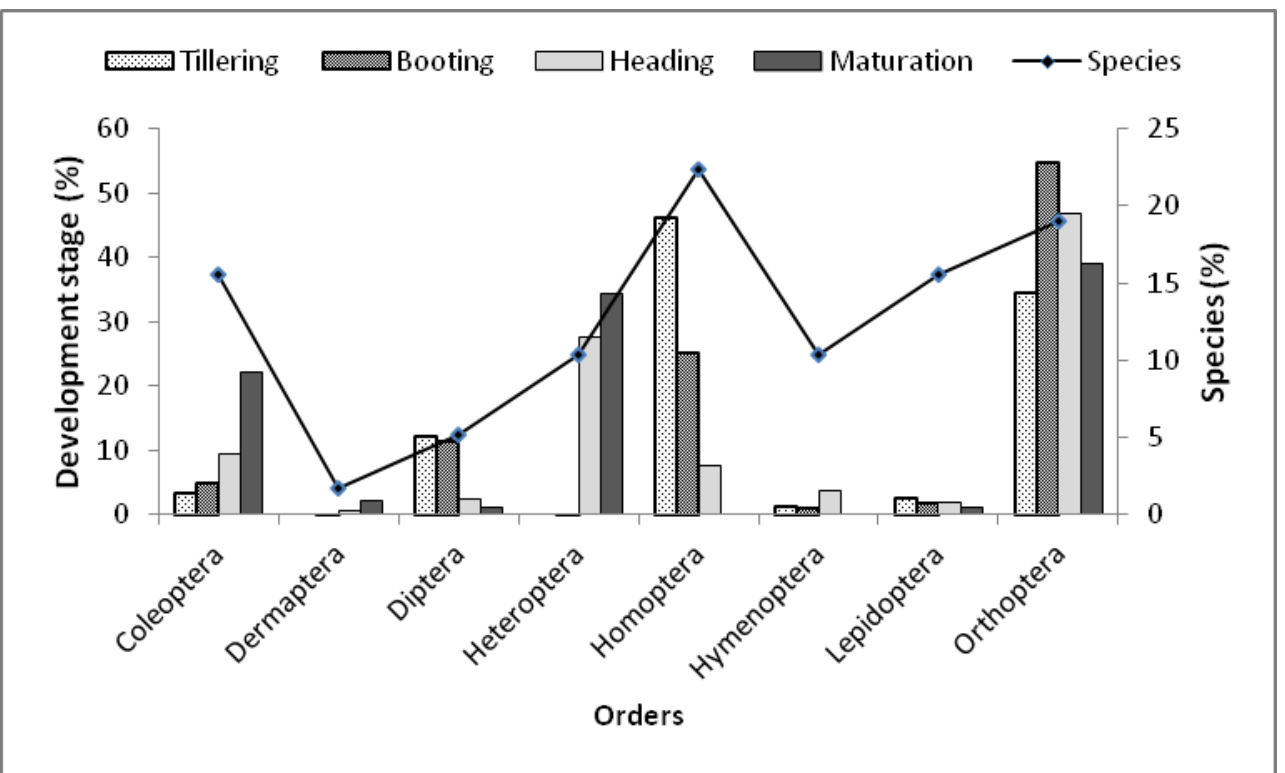

Figure 4: Diversity and abundance of insect orders according rice developmental stages in Koussin site.

Diversity and abundance of insect orders by rice growing stage at Ouedeme: Eight orders, 25 families and 53 species of insects were collected with preponderance at booting compared to other stages. Homopterans were the most abundant at tillering $(41.67 \%)$ and booting (21.94\%). Heteropterans were the order mostly found at heading (28.19\%) and maturation $(67.09 \%)$. As regards the number of species $(P=0.03)$, Homoptera order, was mostly reported amounting to $22.64 \%$. They were followed by Coleoptera $(18.87 \%)$ and Orthoptera (18.87\%) orders. Dermaptera order was represented by only one species (1.89\%) (Figure 5). 


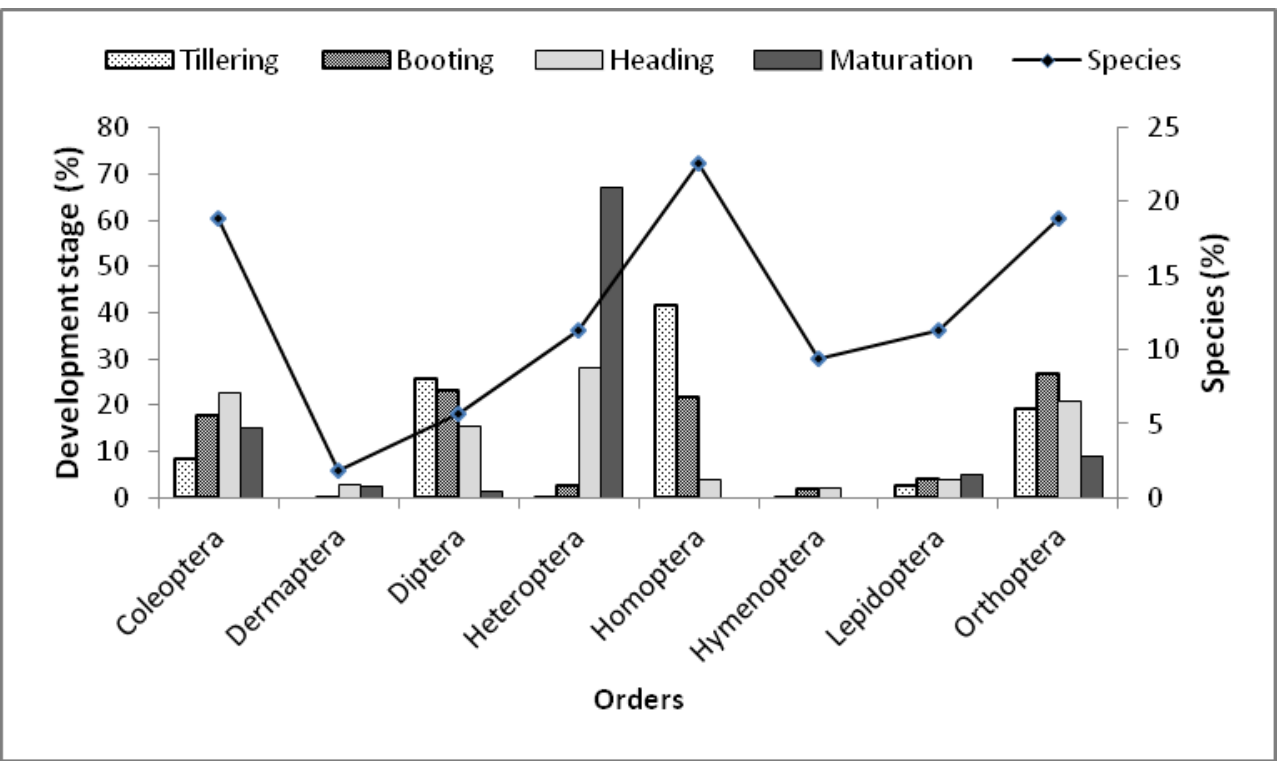

Figure 5: Diversity and abundance of insect orders according rice developmental stages in Ouedeme site.

Frequency of occurrence and relative abundance of collected insect species collected in all sites: These insects were phytophagous ( $87.75 \%$ ), parasitoids (8.75\%) and predators $(7.5 \%)$ (Figure 6). The most frequent and abundant insects belonged to the Homoptera, Coleoptera, Orthoptera and Diptera orders with the relative abundance and frequency of occurrence higher than $2 \%$ and $50 \%$ respectively. Approximately 80 insect species, $23.75 \%$ were already identified as RYMV vectors (Table 3). Cofana spectra (Distant), Cofana unimaculata (Signoret) and Nephotettix modulatus (Melichar) were the most important homopterans. Among the coleopterans, Chnootriba similis (Mulsant), Aulacophora foveicollis (Lucas) and Xanthadalia effusa (Erichson) were the most common species found. In the Orthoptera order, the major species were Oxya hyla (Serville) and Conocephalus longipennis (de Haan). Oxya hyla was the most reported species in all the survey area with $90 \%$ and $10.62 \%$ of occurrence and abundance, respectively. In the Diptera order, Diopsis thoracica (Westwood) and Diopsis apicalis (Dalman) were the most common species (Table 3).

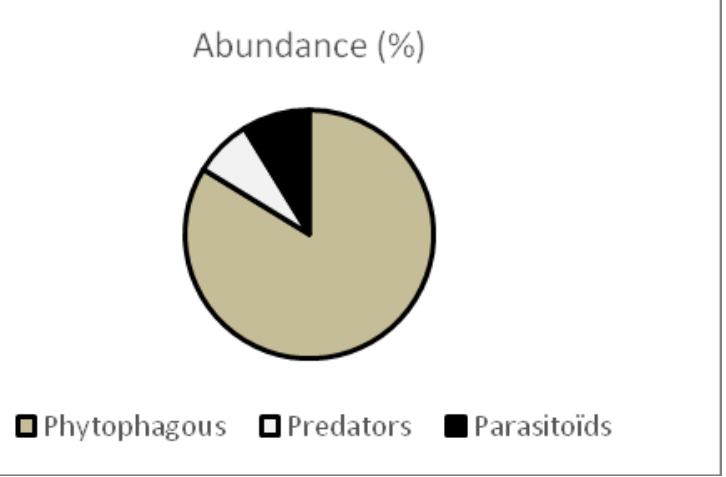

Figure 6. Abundance of insect species according the feeding mode. 
Table 3. Frequency of occurrence and relative abundance of insect species in all sites

\begin{tabular}{|c|c|c|c|}
\hline \multirow{17}{*}{$\begin{array}{l}\text { Orders } \\
\text { Homoptera }\end{array}$} & Species & $A(\%)$ & $F(\%)$ \\
\hline & Poophilus costalis Walker* & 2.29 & 46.67 \\
\hline & Poophilus sp. & 0.91 & 23.33 \\
\hline & Cofana unimaculata Signoret* & 3.94 & 63.33 \\
\hline & Cofana spectra Distant* & 7.99 & 73.33 \\
\hline & Deltocephalus schmidtgeni Wagner & 0.65 & 30.00 \\
\hline & Nephotettix sp. & 0.87 & 50.00 \\
\hline & Nephotettix modulatus Melichar* & 4.45 & 53.33 \\
\hline & Nephotettix afer Ghauri & 1.29 & 40.00 \\
\hline & Hortensia sp. & 0.11 & 10.00 \\
\hline & Empoasca fascialis Jacobi & 0.38 & 23.33 \\
\hline & Locris rubra Fabricius* & 0.31 & 23.33 \\
\hline & Locris maculata Fabricius* & 0.09 & 10.00 \\
\hline & Nilaparvata maeander Fennah & 0.13 & 10.00 \\
\hline & Sogatodes cubanus Crawford & 0.56 & 33.33 \\
\hline & Rhopalosiphum padi L. & 6.08 & 20.00 \\
\hline & Sitobion graminis Takahashi & 5.14 & 23.33 \\
\hline \multirow[t]{16}{*}{ Coleoptera } & Cryptocephalus sp. & 0.07 & 6.67 \\
\hline & Aulacophora foveicollis Lucas* & 1.34 & 63.33 \\
\hline & Chaetocnema pusilla Laboissiere & 0.20 & 13.33 \\
\hline & Chaetocnema pulla Chapuis* & 0.76 & 16.67 \\
\hline & Chaetocnema sp. & 0.24 & 20.00 \\
\hline & Lema rubricollis Klug & 0.11 & 10.00 \\
\hline & Lema sp. & 0.18 & 13.33 \\
\hline & Medythia quaterna Fairmaire & 0.22 & 20.00 \\
\hline & Dicladispa viridicyanea Kraatz* & 0.29 & 23.33 \\
\hline & Sitophilus oryzae L. & 0.18 & 23.33 \\
\hline & Sitophilus zeamais Motschulsky & 0.11 & 13.33 \\
\hline & Chnootriba similis Mulsant* & 5.19 & 80.00 \\
\hline & Chilocorus sp. & 0.22 & 20.00 \\
\hline & Xanthadalia effusa Erichson* & 3.49 & 60.00 \\
\hline & Cheilomenes lunata Fabricius* & 0.42 & 36.67 \\
\hline & Tenebrio sp. & 0.04 & 6.67 \\
\hline \multirow[t]{16}{*}{ Orthoptera } & Oxya hyla Serville* & 10.62 & 90.00 \\
\hline & Oxya sp. & 1.40 & 50.00 \\
\hline & Paracinema tricolor Thunberg* & 0.87 & 30.00 \\
\hline & Acrida bicolor Thunberg ${ }^{*}$ & 1.25 & 40.00 \\
\hline & Acrida turrita L. & 0.22 & 16.67 \\
\hline & Acrida sp. & 1.58 & 53.33 \\
\hline & Stenohippus aequus Uvarov* & 1.20 & 20.00 \\
\hline & Stenohippus sp. & 0.78 & 40.00 \\
\hline & Conocephalus longipennis de Haan* & 4.74 & 90.00 \\
\hline & Phaneroptera sp. & 0.96 & 53.33 \\
\hline & Zonocerus variegatus L.* & 0.22 & 23.33 \\
\hline & Attractomorpha sp. & 0.45 & 33.33 \\
\hline & Metioche sp. & 0.33 & 20.00 \\
\hline & Gryllotalpa africana Beauvois & 0.09 & 13.33 \\
\hline & Paratettix sp. & 2.78 & 23.33 \\
\hline & Euscyrtus sp. & 2.18 & 36.67 \\
\hline Heteroptera & Aspavia armigera Fabricius & 3.36 & 43.33 \\
\hline
\end{tabular}




\begin{tabular}{|c|c|c|c|}
\hline & Aspavia sp. & 0.11 & 10.00 \\
\hline & Agonoscelis versicolor Fabricius & 0.02 & 3.33 \\
\hline & Nezara viridula L. & 0.36 & 43.33 \\
\hline & Rhinocoris albopilosus Signoret & 0.24 & 26.67 \\
\hline & Mirperus jaculus Thunberg & 0.40 & 26.67 \\
\hline & Riptortus dentipes Fabricius & 0.65 & 50.00 \\
\hline & Cletus fuscescens Walker & 0.11 & 6.67 \\
\hline & Anoplocnemis tristator Fabricius & 0.20 & 13.33 \\
\hline & Creontiades sp. & 0.04 & 6.67 \\
\hline Diptera & Diopsis thoracica Westwood ${ }^{*}$ & 7.01 & 80.00 \\
\hline & Diopsis apicalis Dalman & 2.76 & 63.33 \\
\hline & Dasyphora sp. & 0.04 & 6.67 \\
\hline & Argyrophylax nigrotibialis Baranov & 0.96 & 40.00 \\
\hline Lepidoptera & Nymphula depunctalis Guenée & 0.65 & 43.33 \\
\hline & Marasmia trapezalis Walker & 0.07 & 10.00 \\
\hline & Chilo zacconius Bleszynski & 0.60 & 33.33 \\
\hline & Chilo sp. & 0.29 & 30.00 \\
\hline & Eldana saccharina Walker & 0.13 & 16.67 \\
\hline & Maliarpha separatella Ragonot & 0.45 & 36.67 \\
\hline & Sesamia calamistis Hampson & 0.71 & 46.67 \\
\hline & Sesamia sp. & 0.04 & 6.67 \\
\hline & Spodoptera sp. & 0.07 & 6.67 \\
\hline & Sitotroga cerealella Olivier & 0.20 & 23.33 \\
\hline Hymenoptera & Bracon sp. & 0.24 & 20.00 \\
\hline & Stenobracon deesae Cameron & 0.13 & 13.33 \\
\hline & Cotesia sesamiae Cameron & 0.49 & 26.67 \\
\hline & Opius sp. & 0.24 & 33.33 \\
\hline & Pediobus furvus Gahan & 0.29 & 26.67 \\
\hline & Telenomus sp. & 0.58 & 40.00 \\
\hline & Apis mellifera $\mathrm{L}$. & 0.33 & 23.33 \\
\hline Dermaptera & Diaperasticus sp. & 0.29 & 30.00 \\
\hline Total & 80 & 100 & \\
\hline
\end{tabular}

In total, 80 insect species were identified in survey area. Insect species known as RYMV vectors in this area were reported with asterisk $\left({ }^{*}\right)$. A: Relative Abundance, F: Frequency of Occurrence

Apart from these major insects, the homopterans Poophilus costalis (Walker), Rhopalosiphum padi (L.) and Sitobion graminis (Takahashi), the orthopterans Paratettix sp., Euscyrtus sp., Acrida bicolor (Thunberg) and Paracinema tricolor (Thunberg), the heteropteran Aspavia

\section{DISCUSSION}

To know the potential insect vectors of the RYMV in the rice basin of the Southern and Central of Benin, prospections were done in the three rice production sites. Eighty species belonging to 8 orders were identified in the rice basin of Southern and Central Benin. About a quarter of recorded insect species were already identified as vectors (Nwilene, 1999; Koudamiloro et al., 2014; Koudamiloro et al., 2015). Sixty species representing three quarter of the total species were found at least in armigera (Fabricius), the lepidopterans Sesamia calamistis (Hampson), Nymphula depunctalis (Guenée) and Chilo zacconius (Blesynski) and the hymenopterans Telenomus sp. and Cotesia sesamiae (Cameron) were also frequently found in the survey area (Table 3).

two sites. Indeed, rice plant is a preferred host for many insects. Each part of this plant (from root to panicle) can be damaged by various insects. In West Africa, 330 insect species were identified in rice fields (Heinrichs \& Barrion, 2004). The rice basin of south and central Benin was characterized by favorable climatic and environmental conditions such as moderate temperature $\left(24-30{ }^{\circ} \mathrm{C}\right)$, rainfall (80.0-120.0 $\mathrm{cm}$ year-1), heavy vegetation and high relative humidity (85-90\%) (MAEP, 2009). These 
conditions are appropriate for insect development. Moreover, data of Shannon and Simpson indices pinpointed that pest diversity was closer within development stages and sites. Thus, it can be stated that the distribution of insect species in different sites of the basin is homogeneous. However, the higher number of insect species observed at AfricaRice research station compared to Koussin and Ouedeme might be due to the simultaneous presence of two ecosystems of rice production (upland and irrigated lowland) and other crops (maize, cowpea, cassava, and vegetables) in the site. These crops can serve as alternative or associated host for a wide range of rice insects such as $C$. similis, Nephotettix spp., Poophilus spp., Sitophilus spp., S. calamistis, Eldana saccharina (Walker) and Diopsis spp. The abundance of insect species in the AfricaRice station may also be due to the varietal diversity of cultivated rice. Indeed, several varieties of New Rice for Africa (NERICA) and rice populations such as International Rice (IR), Tropical Oryza glaberrima (TOG) and Near Isogenic Lines (Nil) are grown in many experimental trials. The insects will be able to select the most appropriate rice variety to their development cycle and multiplication as reported by Nwilene et al. (2008). For the distribution of insects by orders, homopterans were the most abundant due to the high number of aphids $R$. padi and S. graminis in the AfricaRice field. They were followed by orthopterans and coleopterans, which were observed in all rice growing stages especially at tillering and booting. These stages are high yielding biomass steps, which are favorable for both insect feeding and refuge. Dipterans were highly represented by Diopsis spp. These stem borers can grow easily and even become sedentary in the event of continuous cropping in the same environment (Banwo, 2002; Togola et al., 2010), as reported in this study. Other important stem borers (lepidopterans) commonly found on rice in Benin such as $S$. calamistis, Chilo spp. and $E$. saccharina (Togola et al., 2010), were not significant among the recorded samples perhaps because the dissections of rice tiller were not performed in this study, even though their typical symptoms such as dead hearts and white panicles were observed in the fields. All these orders were among the most important rice pests in West Africa as reported by Brenière (1983) and Heinrichs and Barrion (2004). Regarding the species distribution in the

\section{CONCLUSION}

Diversity and abundance of insect species were studied in the Southern and Central rice basin of Benin and 80 insect species belonging to 8 orders were found. During the vegetative stage i.e. tillering and booting when rice is basin, 0 . hyla was the most frequent and the most abundant. The locust was found in all rice ecosystems (Dale, 1994). According to Nwilene et al. (2011), it was one of the most important pests of rice in fields. Some studies reported that this insect was present throughout the year in other rice growing areas like Côte d'Ivoire and Guinea where similar studies were conducted (Heinrichs \& Barrion, 2004). During their prospections, Paraïso et al. (2012) recorded this insect in all ecological zones of Benin with high density in humid areas such as the study basin. For the beetle, $C$. similis was the most present. The ladybird beetle was one of the major rice pests especially in the upland ecosystem as specified by Sadou et al. (2014). It was found at the vegetative stages of rice in all sites, probably due to the presence of many host plants such as rice, maize, sorghum, millet (Heinrichs, 1991; Tuey, 1999). For the homopterans, C. spectra was the most abundant. It is a cosmopolitan species, from the tropics of Africa to Australia according Wilson and Claridge (1991). In West Africa, this polyphagous insect is present in the lowland ecosystem similarly to most rice leafhoppers (Dale, 1994; Heinrichs \& Barrion, 2004). The dipteran $D$. thoracica, was also one of the major insects found in the basin. It is one of 10 main insect pests of rice in West Africa and one of the four major rice stem borers in Africa (Heinrichs \& Barrion, 2004; Nwilene et al., 2011). It is mainly found in irrigated lowlands as confirmed in this study. These 4 important insect species were also RYMV vectors according several studies (Koudamiloro et al., 2015). Among the entomofauna in the South and Central rice basin of Benin, natural enemies found were predators and parasitoids. The most important predators belonged to the Orthoptera and Coleoptera. Among them were sampled Metioche sp., and C. longipennis, which attack bugs (Shepard et al., 1991; Van den Berg et al., 1992), C. Iunata and $X$. effusa are aphids predators (Brown, 1972; Sadou et al., 2014). The parasitoids belonged to the Hymenoptera and Diptera orders, which contain the most important rice parasitoids in West Africa (Polaszek, 1998; Heinrichs \& Barrion, 2004). They were mostly found at the AfricaRice station where stem borers were also more frequent. Telenomus sp. was the most abundant probably because being the larval parasitoid of $C$. longipennis (Agyen-Sampong, 1980) which was found at high density in the basin.

more susceptible to RYMV, the following four orders Homoptera, Orthoptera, Coleoptera and Diptera were the most frequent and abundant. Among the most frequent species were 0 . hyla, C. similis, C. spectra and $D$. 
thoracica. Future research efforts should focus on the determination of RYMV vector transmission ability of the

\section{ACKNOWLEDGMENTS}

The authors are grateful to Dr Georg Goergen of the International Institute of Tropical Agriculture (IITA) for the identification of some insect species, Dr Drissa Silue and Dr Nasser K. Yao, for their useful comments on this manuscript. We also acknowledge the farmers in the study area for their helpful collaboration. Our greatest

\section{REFERENCES}

Agyen-Sampong M (1980). Parasites of rice pests of mangrove swamps in northern Sierra Leone. WARDA Technical Newsletter 2: 1-3.

Alegbejo MD, Raji BA, Abubakar IU \& Banwo OO (2006). Rice yellow mottle virus disease, a new disease of rice in Zamfara, Nigeria. International Rice Research Notes 31(39): 39-39.

Alhmedi A, Francis F, Bodson B \& Haubruge E (2007). Évaluation de la diversité des pucerons et de leurs ennemis naturels en grandes cultures à proximité de parcelles d'orties. Notes Fauniques de Gembloux 60: 147-152.

Bakker W (1971). Three new beetle vectors of rice yellow mottle virus in Kenya. Netherlands Journal of Plant Pathology 77: 201-206.

Banwo 00 (2002). Management of Major Insect Pests of Rice in Tanzania. Plant Protection Science 38: 108-113.

Banwo OO, Alegbejo MD \& Abo ME (2004). Rice yellow mottle virus genus Sobemovirus: a continental problem in Africa. Plant Protection Science 40: 26-36.

Brenière $\mathrm{J}$ (1983). The principal insect pests of rice in West Africa and their control. West Africa Rice Development Association, Monrovia (Liberia), p. 87.

Brown HD (1972). Predacious behavior of four species of Coccinellidae (Coleoptera) associated with wheat aphid, Schizaphis graminum (Rondani), in South Africa. Transactions Royal Entomological Society London 124: 21-36.

Calvert LA, Koganezawa H, Fargette D \& Konaté G (2003). Rice. pp. 269-294 in G. Loebenstein and Thottappilly, G. (Eds.) Virus and virus-like diseases of major crops in developing countries. Dordrecht, the Netherlands, Kluwer Academic Publishers.

Dajoz R (1985). Précis d'écologie. Bordas Paris, p. 505. main insect species found in the rice basin.

thanks are due to Dr Francis Nwilene, who was the head of Entomology Unit of AfricaRice Center. This study was supported in part by AfricaRice Center through the budget ENTO1 0201/JAPAN1 and the scholarship of Ministry of High Education and Scientific Research of Benin Republic.

Dale D (1994). Insect pests of the rice plant - their biology and ecology. pp. 363-485 in E. A. Heinrichs. (Ed.) Biology and management of rice insects. New Delhi, Wiley Eastern.

Delvare G \& Aberleng P (1989). Les insectes d'Afrique et d'Amérique tropicale. Clé pour la reconnaissance des familles. Lab fauna, department of GERDAT, Montpellier, France, p. 302.

Dupriez H, Silas N \& Colin J (2001). Champs et jardins sains: lutte intégrée contre les maladies et les ravageurs des cultures. Nivelles, Belgique $p$. 238.

Heinrichs EA (1983). Biology and management of rice insects. Academic Press, New York, p. 777.

Heinrichs EA (1991). Lowland rice insect pest populations and their effect on grain yields. pp. 55-57 WARDA annual report 1991. Bouaké (Côte d'Ivoire): West Africa Rice Development Association.

Heinrichs EA \& Barrion AT (2004). Rice-Feeding Insects and Selected Natural Enemies in West Africa. Biology, ecology, identification. IRRI/WARDA, Los Baños/Abidjan, p. 243.

Konaté G, Fargette D \& Traoré O (2008). Conséquences de la biodiversité du RYMV sur l'amélioration variétale du riz. p. 12 in Proceedings of the Biodiversité et amélioration des plantes en Afrique sub-saharienne, Montpellier (France), 2008.

Koudamiloro A, Nwilene FE, Togola A \& Akogbeto M (2015). Insect Vectors of Rice Yellow Mottle Virus. Journal of Insects ID 721751: 12 pages, http://dx.doi.org/10.1155/2015/721751.

Koudamiloro A, Nwilene FE, Silue D, Togola A, Oyetunji 0 , Sere Y \& Akogbeto M (2014). Identification of Insect Vectors of Rice yellow mottle virus (RYMV) in Benin. Journal of Entomology 11: 153-162. 
Limoges R (2003). Méthode de capture 2, Insectarium de Montréal <http:// www2.villemontreal.qc.ca>.

MAEP (2009). Projet de renforcement des capacités nationales de suivi des ressources en eau axé sur la gestion de l'eau agricole pp. 75 .

Magurran AE (2004). Measuring Ecological Diversity. Blackwell Publishing, Oxford, p. 256.

Nwilene FE (1999). Current status and management of insect vectors of Rice yellow mottle virus (RYMV) in Africa. International Journal of Tropical Insect Science 19(2/3): 179-185.

Nwilene FE, Traore AK, Asidi AN, Sere Y, Onasanya A \& Abo ME (2009). New records of insect vectors of rice yellow mottle virus (RYMV) in Cote d'Ivoire, West Africa. Journal of Entomology 6(4): 189197.

Nwilene FE, Jones MP, Brar DS, Youm O, Togola A, Kehinde A, Ukwungwu MN, Kamara SI \& Hamadoun A (2008). Integrated Pest Management (IPM) strategies for NERICA varieties. pp. 83-94 in E. A. Somado, Guei, R. G. and Keya, S. O. (Eds.) NERICA: the New Rice for Africa - a Compendium. Cotonou, Benin/Rome, Italy/Tokyo, Japan, Africa Rice Center (WARDA)/FAO/Sasakawa Africa Association.

Nwilene FE, Togola A, Oyetunji OE, Onasanya A, Akinwale G, Ogah E, Abo E, Ukwungwu M, Youdeowei A \& Woin N (2011). Is pesticide use sustainable in lowland rice intensification in West Africa? pp. 300 in M. Stoytcheva. (Ed.) Pesticides in the modern world: risks and benefits. Rijeka, Croatia, inTech.

Onwughalu JT, Abo ME, Okoro JK, Onasanya A \& Sere $Y$ (2010). The Effect of Rice yellow mottle virus infection on the performance of rice (Oryza sativa L.) relative to time of Infection under screenhouse condition. Journal of Applied Sciences 10: 1341-1344.

Onwughalu JT, Abo ME, Okoro JK, Onasanya A \& Sere $Y$ (2011). Rice yellow mottle virus infection and reproductive losses in rice (Oryza sativa Linn.). Trends in Applied Sciences Research 6: $182-$ 189.

Paraïso AA, Douro-kpindou OK, Onzo A, Odjo AT, Ahomagnon V, Obognon F \& Godonou I (2012). The acridoidea of Benin (Orthoptera): an annoted checklist. International Journal of Science and Advanced Technology 2: 22-52.
Peters D, Engels C \& Sarra S (2012). Natural Spread of Plant Viruses by Birds. Journal of Phytopathology 160: 591-594.

Polaszek A (1998). African cereal stem borers: economic importance, taxonomy, natural enemies and control. CAB International, Wallingford, Oxon, (UK), p. 530.

Rolot J-L (2005). Analysis of factors controlling the spread of the potato virus $Y$ (PVY) for pest management strategies. Gembloux, Belgique, University Faculty of Agronomic Sciences. PhD thesis, p 252

Roth M (1963). Comparaisons de méthodes de capture en écologie entomologique. Revue de pathologie végétale et d'entomologie agricole de France T. XLII-3: 178-197.

Sadou I, Woin N, Djonwanwe \& Mbongaya SE (2014). Study of the population of coleoptera in irrigated rice ecosystems (Maga and Yagoua) and in Upland rice in Maroua. European Journal of American Studies 5: 71-76.

Sadou I, Woin N, Ghogomu TR \& Djonmaila KM (2008). Inventaire des insectes ravageurs et vecteurs de la panachure jaune du riz dans les périmètres irrigués de Maga (Extrême Nord Cameroun). Tropicultura 26(2): 84-88.

Sarra S \& Peters D (2003). Rice yellow mottle virus is transmitted by cows, donkeys and grass rats in irrigated rice crops. Plant Disease 87: 804-808.

Séré $Y$, Onasanya A, Nwilene FE, Abo ME \& Akator K (2008). Potential of insect vector screening method for development of durable resistant cultivars to Rice Yellow Mottle Disease. International Journal of Virology 4(2): 41-47.

Shepard BM, Barrion AT \& Litsinger JA (1991). Helpful insects, spiders and pathogens: friends of the rice farmer pp. 137 in IRRI. (Ed.) Manila (Philippines), International Rice Research Institute.

Sylvie B (1995). Comparative effectiveness of some methods of trapping on some beetles and influence of anthophilie on the result of captures. Bulletin de la Société Neuchâteloise des Sciences Naturelles 118: 39-52.

Togola A, Nwilene FE, Hell K, Oyetunji OE \& Chougourou D (2014). Impact of climatic and environmental factors on the distribution of Sitotroga Cerealella (Olivier) and Sitophilus Oryzae (Linnaeus) in Benin. European Journal of Scientific Research 120: 112-121. 
Togola A, Nwilene FE, Agbaka A, Anato F, Agunbiade TA \& Chougourou DC (2010). Connaissance paysanne des insectes foreurs de tiges du riz et leurs dégâts dans différentes zones écologiques du Bénin (Afrique de l'Ouest) Cahiers Agricultures 19: 262-266.

Togola A, Nwilene FE, Agbaka A, Degila F, Tolulope A \& Chougourou D (2011). Screening Upland Varieties of NERICA and its Parents for Resistance to Stalk-eyed Fly, Diopsis sp. (Diptera, Diopsidae) in Benin. Journal of Applied Sciences 11: 145-150.

Togola A, Kotoklo EA, Nwilene FE, Amevoin K, Glitho IA, Oyetunji OE \& Kiepe P (2012). Specific Diversity and Damage of Termites on Upland Rice in Benin. Journal of Entomology 9: 352-360.

Tuey RK (1999). The Biology and Ecology of the Epilachnid beetle Chnootriba similis Thunberg (Coleoptera: Coccinellidae) Newcastle upon Tyne, UK, University of Newcastle. PhD thesis, $p$ 150.

Van den Berg H, Litsinger JA, Shepard BM \& Pantua PC (1992). Acceptance of eggs of Rivula atimeta, Naranga aenescens (Lep. Noctuidae) and Hydrellia philippina (Dipt. Ephydridae) by insect predators on rice. Entomophaga 37: 21-28.

Wilson MR \& Claridge MF (1991). Handbook for the identification of leafhoppers and planthoppers of rice. $C A B$ International, Wallingford, Oxon, $p$. 142. 